\title{
SOME HISTOLOGICAL RESPONSES NEW ZELAND RABBITS TO DRINKING WATER POLLUTED BY PROFENOFOS
}

\author{
S.M. Salem ${ }^{1}$ and M.I. Kobeasy ${ }^{2}$ \\ 1- Department of Animal Production, Faculty of Agriculture, University of \\ Cairo, Giza, Egypt 2- Department of Biochemistry, Faculty of Agriculture, \\ University of Cairo, Giza, Egypt
}

\section{SUMMARY}

The present investigation was carried out on New Zealand made rabbits $(n=30)$ to determine the histological responses of liver, kidney and thyroid glands with the polluted water by different concentrations of profenofos. The animals exposed to the polluted water for 90 days. Bucks ( $n=10$ per group) given sub-lethal doses of $75 \mathrm{ppm}$ and 150ppm profenofos in drinking water showed a decrease $(P<0.05)$ in body weight gain after 30,60and 90 days of treatment by29\%, 36.4\% and $44.5 \%$ for 150 ppm, respectively, while no significant changes in the weight of liver, kidney, spleen, lung, heart and brain of New Zealand bucks were observed. There was an increase $(p<0.05)$ by $6 \%$ and $8.5 \%$ in liver weight of bucks treated by 75 ppm and 150 ppm of profenofos, respectively. The liver of bucks treated with 75 ppm of profenofos for 90 days, showed hyperemic central vein and sinusoids, associated by mononuclear luekocytic inflammatory cell aggregation in the hepatic tissue. The portal area showed edema with severe dilation in the portal vein as well as hyperplasma in the bile duct. The hepatic tissue of bucks exposed to 150 ppm of profenofos showed hyperemic central veins and sinusoids of the hepatocytes, associated with diffuse kupffer cells proliferation. There was thickening in the Bowman's capsule with edema, fibrosis and inflammatory cells infiltration in the oeriglomerular tissue. Perivascular mononuclear leucocytic inflammatory cells infiltration was observed, associated with degenerative change in the epithelial cells lining the renal tubules which had casts in their lumenae. The thyroid gland of male rabbits treated with 75 ppm of profenofos for 90 days, showed degeneration and desquamation of the lining epithelium of some acini and the acinar lumenae were completely free from the colloid.

Keywords: Histology, liver, kidney, thyroid, profenofos, rabbits

\section{INTRODUCTION}

Organophosphorus compounds are part of a large group of synthetic pesticides that have been developed in the last 50 years, and are commonly used in agricultural and public health. Due to their wide use, contamination of food, water, and air has become imminent and consequently adverse heath effects are inevitable in humans, animals, and fish (Gupta, 1994). The use of pesticides not only increased the crop yields but also helped in controlling ectoparasites on livestock. However, widespread

Issued by The Egyptian Society of Animal Production 
use of these chemicals is not without risks. There have been several instances of poisoning in animals. Animals get exposed to these pesticides due to their inadvertent use for the control of ectoparasites and insects in the vicinity of poultry, rabbits, and animal houses. Residues of the grain protectant pesticides may also come in animal feeds. The aim of this study is to examine the effect of drinking polluted water by 75 and $150 \mathrm{ppm}$ of the profenofos for 90 consecutive days on body weight, and the weight of liver, kidney, and thyroid gland. Also to state the histological responses of liver, kidney and thyroid glands in male New Zealand rabbits for toxicity of profenofose.

\section{MATERIALS AND METHODS}

\section{Experimental animals}

A number of 30 mature New Zealand male rabbits (Bucks) weighing $2.4 \mathrm{~kg} \pm 0.3$ obtained from the farm of general organization of Serum and Vaccine (Helwan farm) were used in this study. Animals were allowed to acclimatize to laboratory conditions for a minimum period of 3 weeks. The animals were kept on balanced diet throughout the experimental period. Feed and water were available during the time of treatment.

\section{Experimental design}

The experimental bucks were randomly distributed into 3 groups (A, B, and C), each of 10 animals, housed in batteries and given profenofos (Cord or Profenofos) which are used in control of insects and mites on animals and some crops such as, sugar beat, soybeans, maize, vegetables ect.) through drinking water for 90 successive days. Bucks of group A were kept as a control while those of group B and $\mathrm{C}$ were given a concentrations of 75 and $150 \mathrm{ppm}$ of profenofos in the drinking water. Water consumption of rabbits was recorded daily and the animals were weighed weekly throughout the study.

\section{Tissue samples}

The treated bucks were sacrificed at the end of the experimental period ( 90 days). Some vital organs such as liver, kidney, spleen, heart and lung were removed after sacrificing and their weights were recorded. The liver, kidney, and thyroid gland were fixed in $15 \%$ formalin for histopathological examination. Routine histopathological procedures were carried out according to Harris (1898).

\section{Statistical analysis}

Data were subjected to statistical analysis by least squares means analysis of variance $2 \times 2$ factorial design. The main effects of treatment and duration and all possible interaction terms were included in in the model according to the procedures reported by Snedecor and Cochran (1980); and " $t$ " test was performed to evaluate the difference between mean values of the treated group and those of control group. Values are expressed as mean $\pm \mathrm{SE}$.

\section{RESULTS AND DISCUSSION}

Data presented in Table (1) showed decreases $(\mathrm{P}<0.05)$ in body weight gain after 30,60 and 90 days of treatment $16.7 \%, 34.7 \%$ and $48.5 \%$ for $75 \mathrm{ppm}$; and $29 \%$, 
$36.4 \%$ and $44.5 \%$ for $150 \mathrm{ppm}$ relative to control respectively. The present results are generally similar to those reported by several workers Undeger et al. (2000), noticed that, the body weight gain decreased in the treated groups after 31 and 28 days of treatment, while Ahmed et al. (2000), reported that the body weight gain was significantly increased according to the type of insecticide and the dosage of the used pesticides. On the other hand, Shaker et al. (1988) reported, no effect on body weight gain as a result of synthetic pesticides administration to laboratory animals.

Table 1. Effect of profenofos on body weight $(\mathrm{kg})$ in New Zealand rabbits

\begin{tabular}{lccc}
\hline \multirow{2}{*}{ Period } & \multicolumn{3}{c}{ Treatment Period (days) } \\
\cline { 2 - 4 } Dose & $\mathbf{3 0}$ days & $\mathbf{6 0}$ days & $\mathbf{9 0}$ days \\
\hline Control & $2.4 \pm 0.3$ & $2.3 \pm 0.18$ & $2.5 \pm .25$ \\
$75 \mathrm{ppm}$ & $2.0 \pm 0.11^{\mathrm{a}}$ & $1.5 \pm 0.24^{\mathrm{b}}$ & $1.3 \pm 0.17^{\mathrm{b}}$ \\
$150 \mathrm{ppm}$ & $1.7 \pm .11^{\mathrm{ea}}$ & $1.3 \pm 0.24^{\mathrm{db}}$ & $1.23 \pm .26^{\mathrm{fc}}$ \\
\hline
\end{tabular}

Each value represents mean \pm SE

A,b,c,d,e, and $f$ as superscript means that the differences are significant $(p<0.05)$.

Decreased body weight gain after treatment with profenofos can interfere with metabolic process or may be due to pathological lesions in the gastrointestinal tract, which was reflected in mal-absorption of nutrients in treated groups (Kaneko, 1997). Data in Table (2) indicate that, rabbits treated with different concentrations of profenofos showed no significant changes in the weight of kidney, spleen, lung, heart and brain of New Zealand male rabbits. While there was a significant $(\mathrm{p}<0.05)$ increase in liver weight with treatment by $6 \%$ and $8.5 \%$ for $75 \mathrm{ppm}$ and $150 \mathrm{ppm}$, respectively. The results are in agreement with that obtained Cannon et al., (1979) who mentioned that treatment of rats with by chlordane (kepone) showed no differences in organs weight, except the liver and kidneys.

Table 2. Effect of profenofos on internal organs weight $(\mathrm{g})$ in rabbit after 90 days of treatment period

\begin{tabular}{lccc}
\hline \multicolumn{1}{c}{ Period } & \multicolumn{3}{c}{ 90 days } \\
\cline { 2 - 4 } Weight g & Control & 75 PPM & 150 PPM \\
\hline Liver & $68.2 \pm 11.6$ & $72.5 \pm 14.5^{*}$ & $64.11 \pm 21.3^{*}$ \\
Kidneys & $144.0 \pm 22.1$ & $138.5 \pm 11.5$ & $132.4 \pm 10.5$ \\
Spleen & $50.76 \pm 28.0$ & $48.59 \pm 12.0$ & $46.38 \pm 5.6$ \\
Heart & $72.0 \pm 14.0$ & $66.24 \pm 13.0$ & $71.28 \pm 15.2$ \\
Braine & $60 \pm 10.1$ & $57.1 \pm 15.0$ & $61.8 \pm 14.2$ \\
\hline
\end{tabular}

Each value represents mean \pm SE *Significant differences versus control at $\mathrm{p}<0.05$

Results of the present study disagree with those stated by El Said (1997) and Siroki et al. (2001), who reported a marked increase in weights of liver, spleen, kidney and lung in animals treated with some pesticides. While Undeger et al. (2000) found that the administration of dimethoated and methyl parathion decreased weights of liver and kidney in mail rats. Histopathological studies are used to assess the significance of apparent differences between organ weights of test material-treated and control animals parenthesis (Hayes, 1994). 


\section{Effect of profenofos on liver tissues}

The liver tissue of rabbits of group 1 (control) showed the normal histological structure of the hepatocytes in the hepatic cords and lobules with the central and portal veins (plate1).

The liver of rabbits treated with $75 \mathrm{ppm}$ of profenofos for 90 days showed hyperemic central vein and sinusoids (plates $2 \& 3$ ), associated by mononuclear luekocytic inflammatory cells aggregation in the hepatic tissue (plates $4 \& 5$ ). The portal area showed edema with sever dilation in the portal vein as well as hyperplasma in the bile duct (plate 6). The hepatic tissue of male rabbits given 150 ppm of profenofos showed hyperemic central veins and sinusoids of the hepatocytes, associated with diffuse kupffer cells proliferation (plate 7). Mononuclear luekocytic inflammatory cells aggregation was detected in the portal area with severe dilatation in the portal vein and degeneration in the hepatocytes (plates $8 \& 9$ ). Focal inflammatory cell aggregation as well as infiltration was detected in the hepatic tissue (plate 10). The previous histopathological results are in accordance with the studies of Salem and Kobeasy (2005), which deals with liver function, and each confirmed the other. Mohamed et al. (1995) reported that twelve of fifteen 6-9-mo-old clinically healthy Desert sheep were given single or repeated daily doses of 25 to $4000 \mathrm{mg}$ Cotoran $/ \mathrm{kg}$ by drench. Cotoran poisoning was characterized by grinding of the teeth, ruminal tympany, mydriasis, dyspnea, staggering, paresis of the hind and forelimbs, and recumbency. Lesions were widespread congestion and hemorrhage, hepatic fatty change, catarrhal enteritis and degeneration of the epithelial cells of the renal proximal convoluted tubules were observed. Kim et al. (1998) reported that, in male Sprague rats given a single injection of vinyle carbamate $(125 \mathrm{mg} / \mathrm{kg}$ b.wt) the hepatic damage mainly consisted of centrilobular necrosis with sinusoidal congestion. Also Fujitani et al. (2000) found that, treatment of male and female mice with chloprophan through feeding at concentration of $0,1875,7500$, or $30.000 \mathrm{ppm}$ induced necrosis of hepatocytes.

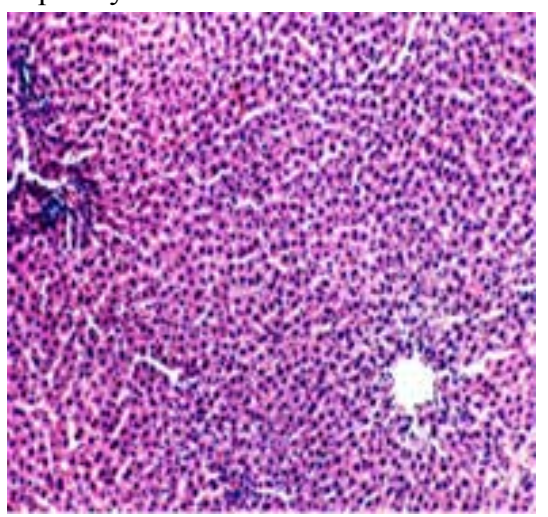

Plate 1. A cross section in liver of untreated rabbits showing the normal histological structure of the hepatocytes in the hepatic cords and lobules with the central vein as well as the portal area. (H.\&E.X40).

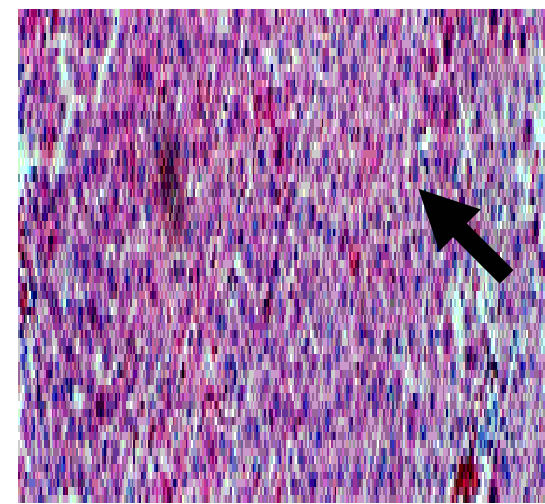

Plate 2. A cross section in liver of rabbits given 75ppm of Profenofos for 90 days, showing hyperemici central vein and sinusoids (H. \&EX40). 


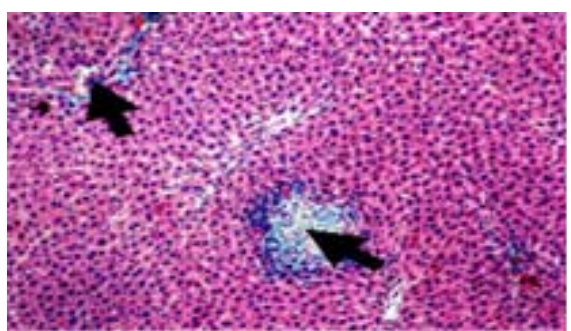

Plate 3. A cross section in liver of rabbits given 75 ppm of Profenofos for 90 days, showing focal necrotic area surrounded by mono nuclear leukocytic inflammatory cells associated with diffuse kupffer cells proliferation. (H \&E.X40)

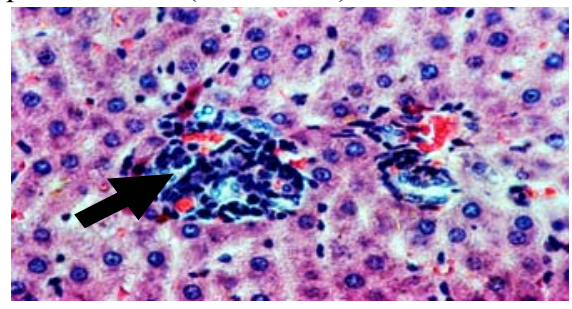

Plate 5. Edema in the sever portal area associated with dilatation of the portal vein and hyperplasia in the epithelial cells lining the bile duct: (H \& E X40)

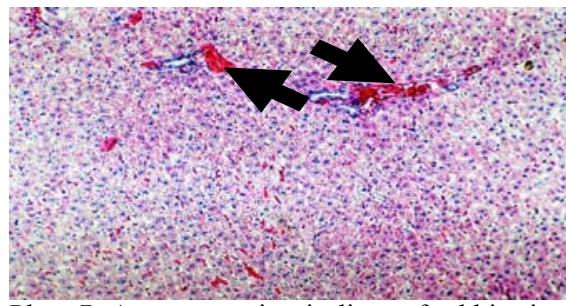

Plate 7. A cross section in liver of rabbit given $150 \mathrm{ppm}$ of Profenofos for 90 days, showing hyperemic central vein and sinusoids with diffuse kupffer cells proliferation (H \& E X10).

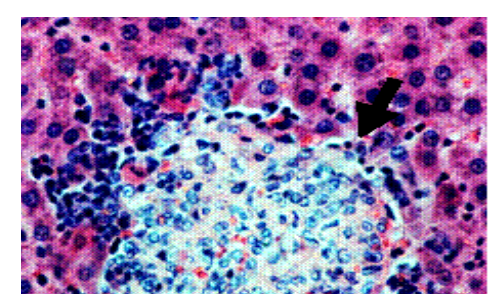

Plate 4. A cross section in liver of rabbit given $75 \mathrm{ppm}$ of Profenofos for 90 days showing the high magnification to clearify the focal necrotic area and inflammatory cells infiltration ( $\mathrm{H} \& \mathrm{E}$ X160)

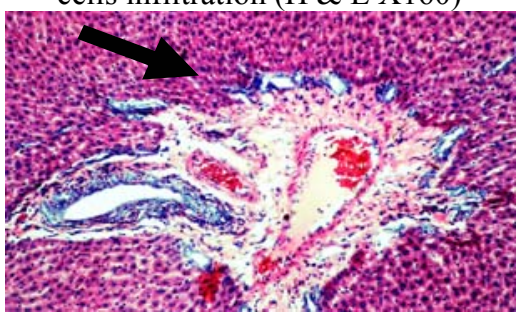

Plate 6. A cross section in liver rabbits given $75 \mathrm{ppm}$ of Profenofos for 90 days showing edema in the portal area associated with sever dilatation of the portal vein and hyperplasia in the epithelial cells lining the bile duct: $(\mathrm{H}$ \& E X40)

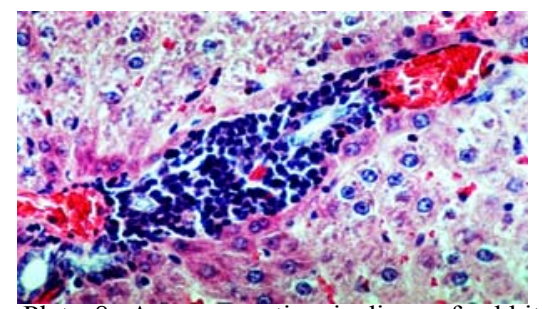

Plate 8. A cross section in liver of rabbit given $150 \mathrm{ppm}$ of Profenofos for 90 days showing mononuclear leukocytic inflammatory cells aggregation in the portal area with dilatation in the portal veins and degeneration in the hepatocytes (H \& EX160). 


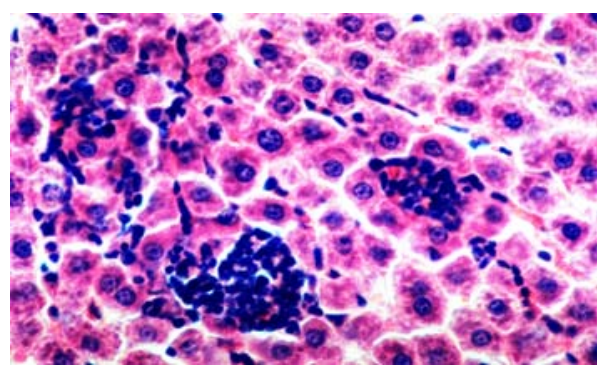

Plate 9. A cross section in liver of rabbit given $150 \mathrm{ppm}$ of Profenofos for 90 days showing focal inflammatory cells aggregation as well as infiltration (H \& EX160)

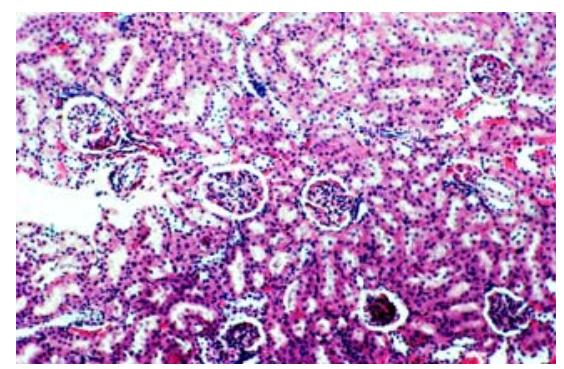

Plate 10. A cross section in kidney of untreated rabbit showing the normal histological structure of the glomeruli and renal tubules (H\&E X40)

\section{Effect of profenofos on kidney tissues}

Plate 10 shows the kidney tissue of untreated male rabbits with normal histological structure. The kidney of male rabbits treated with $75 \mathrm{ppm}$ of Profenofos for 90 days, showed that the glomeruli as well as the inter-tubular blood vessels and capillaries in both cortex and medulla were severely dilated and engorged with blood in association with focal hemorrhagic areas (plates $11 \& 12$ ). There was thickening in the Bowman's capsule with oedema, fibrosis and inflammatory cells infiltration in the oeriglomerular tissue (plate 13). Perivascular mononuclear leukocytic inflammatory cell infiltration was observed (plate 14), associated with degenerative change in the epithelial cells lining the renal tubules which had casts in their lumenae (plate 15). Treatment with $150 \mathrm{ppm}$ profenofos indicated severe hyperemia with focal haemorrhages in both cortex and medulla (plate 16). These changes in kidney confirmed the biochemical results of kidney function Salem and Kobeasy (2005).

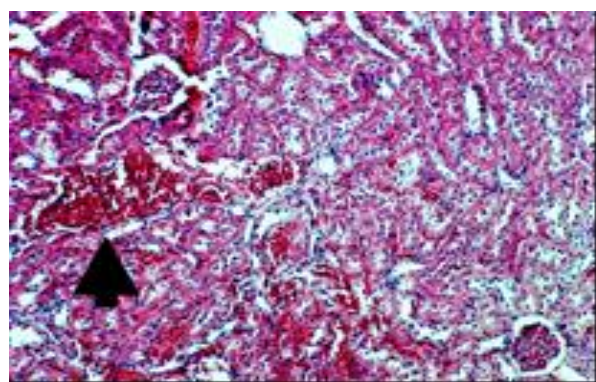

Plate 11. A cross section in kidney of rabbit given $75 \mathrm{ppm}$ of Profenofos for 90 days showing hyperemia in the glomeruli and intertubular blood vessels and capillaries with focal haemorrhagic areas in the cortical portion. (H \& EX40)

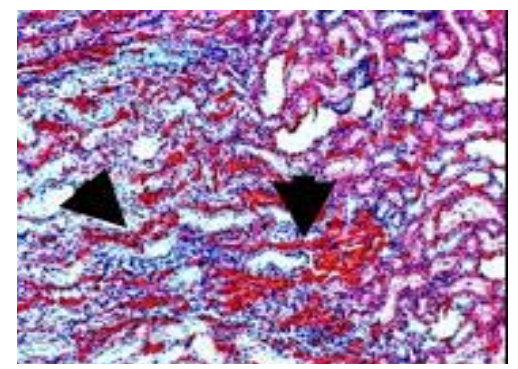

Plate 12. A cross section in kidney of rabbit given $75 \mathrm{ppm}$ of profenofos for 90 days showing sever hypermia with focal haemorrhagic areas in the cortico-medullary function (H \& EX40) 


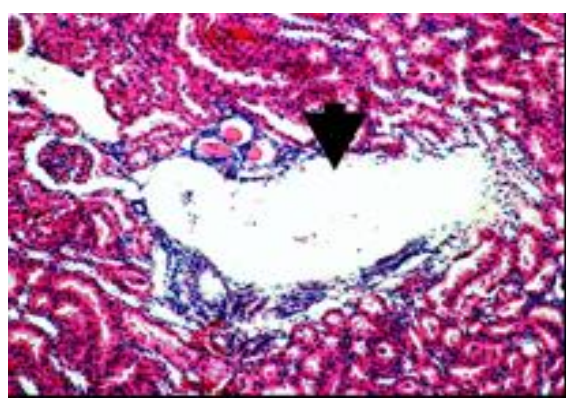

Plate 13. A cross section in kidney of rabbit given $75 \mathrm{ppm}$ of profenofos for 90 days showing thickening of bowmans capsule with oedema, fibrosis and inflammatory cells infiltration in the periglomerular tissue $(\mathrm{H} \&$ EX160)

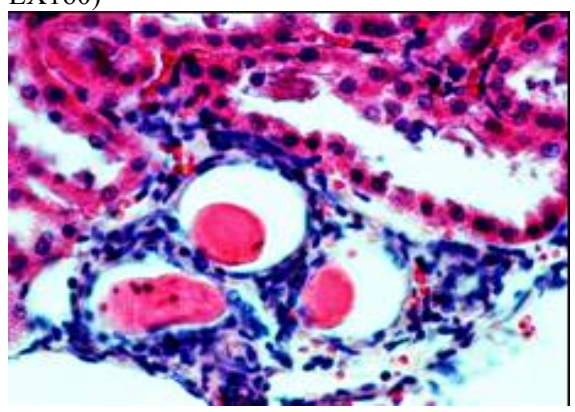

Plate 15. A cross section in kidney of rabbit given $75 \mathrm{ppm}$ of profenofos for 90 days showing degenerative change in the epithelial cells lining the renal tubules with appearance of renal casts in their lumenae (H \& E X160)

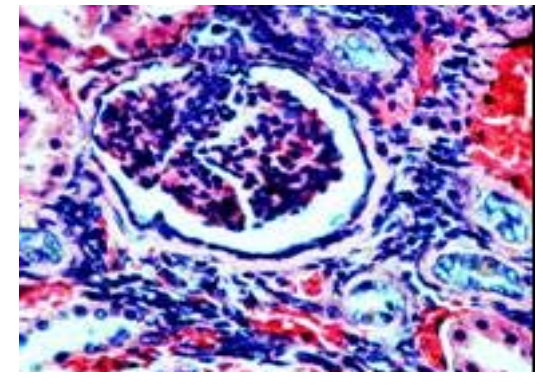

Plate 14. A cross section in kidney of rabbit given $75 \mathrm{ppm}$ of Profenofos for 90 days, showing perivascular mononuclear leucocytic inflammatory cells infiltration (H \& E X40)

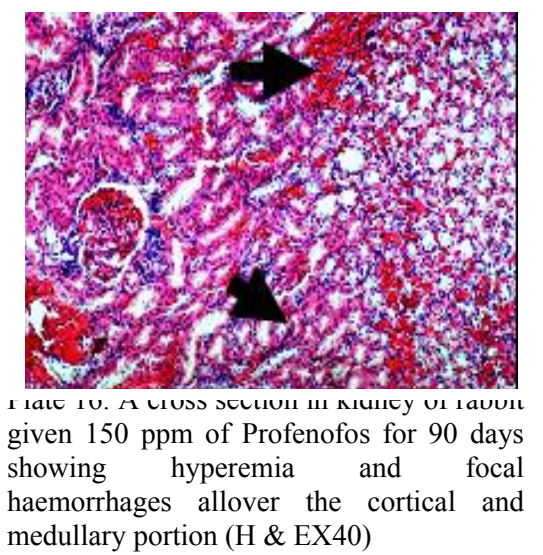

Also these results are in accordance with those obtained by many researchers in Canadian Pest Management Regulatory Agency (2001). They stated that, in the rat 90-d dietary study, some histopathological findings in kidney included degeneration with regeneration in the descending portion of the proximal tubules (females at 500 $\mathrm{mg} / \mathrm{kg}$ bw/d and above) which was considered to be typical of acute necrosis with regeneration rather than a $90-d$ old lesion and multi-focal mineralization in the papilla (females at $800 \mathrm{mg} / \mathrm{kg} \mathrm{bw} / \mathrm{d}$ ). These lesions did not appear to be reversible. In rat 2- year dietary study, other histopathological findings in kidney included a possible slight decreased incidence of age-related tubular degeneration / regeneration and a decreased severity of spontaneous geriatric renal degeneration (chronic progressive glomerularnephropathy) in males at $250 \mathrm{mg} / \mathrm{kg}$ bw/d and above. Slight decreased incidence of spontaneous geriatric renal disease in females at $250 \mathrm{mg} / \mathrm{kg}$ bw/d and minimal reactive hyperplasia of the transitional epithelium and unilateral necrosis of the papilla in males at $500 \mathrm{mg} / \mathrm{kg}$ bw/d. Males with high-dose males also exhibited decreased proteinuria, which may represent less severe chronic renal 
disease although the decreased specific gravity suggest that dilution may have also contributed to lower values.

Body weight and body-weight gain were significantly lower in males at 1000 $\mathrm{mg} / \mathrm{kg} \mathrm{bw} / \mathrm{d}$ and in females at $500 \mathrm{mg} / \mathrm{kg} \mathrm{bw} / \mathrm{d}$ and above in the 90 - $\mathrm{d}$ dietary study and in males at $500 \mathrm{mg} / \mathrm{kg} \mathrm{bw} / \mathrm{d}$ (highest dose tested [HDT]) and in females at 250 $\mathrm{mg} / \mathrm{kg}$ bw/d (HDT) in the 2-year dietary study. This was associated with concomitant lower food consumption in the high-dose animals in both 90 -d and 2-year dietary study.

The subchronic and chronic toxicity of florasulam was investigated in the mouse, rat and dog. A 28-d repeat dose dermal toxicity study was also carried out in rats. In the subchronic and chronic studies, treatment-related findings were observed in the kidney in all species and in the liver and adrenal glands in dogs. In the kidney, hypertrophy of the epithelial cells of the collecting ducts occurred in all tested species. In subchronic and chronic dietary studies, treatment-related findings were observed in kidney of mice, rats and dogs and in the liver and adrenal glands of dog. Hypertrophy of the epithelial cells of the collecting duct was observed in all tested species.

\section{Effect of Profenofos on thyroid gland}

The thyroid gland of untreated male rabbits showed the normal histological structure of the acini and the colloid material in their lumenae as shown in plate (17).

The thyroid gland of male rabbits treated with $75 \mathrm{ppm}$ of profenofos for 90 days, showed degeneration and desquamation of the lining epithelium of some acini, and the acinar lumenae were completely free from the colloid plate (18). Histopathological examination of thyroid gland of animals treated by $150 \mathrm{ppm}$ of profenofose showed few atrophy and colloid free lumen in few acini (plate 20). The histopathological findings confirmed the biochemical aspects of thyroid gland Salem and Kobeasy (2005).

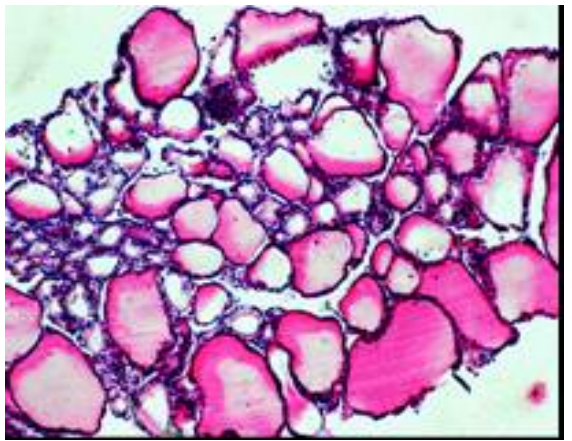

Plate 17. A cross section in thyroid gland of untreated rabbit showing the normal histological structure of the acini and the colloid material in their lumenae (H\&E. X40)

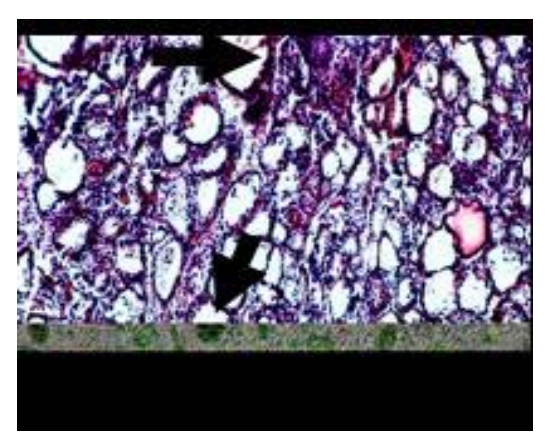

Plate 18. A cross section in thyroid gland of rabbit given $75 \mathrm{ppm}$ of profenofos for 90 days showing the acini completely free from the colloid (H\&EX40) 


\section{CONCLUSION}

The studied criteria included the changes in body weight, and giblets. Histological changes in liver, kidney and thyroid gland due to drinking polluted water by profenofos for 90 days with two concentrations (75 and $150 \mathrm{ppm}$ ). Profenofos induced a significant increase in body weight gain after 30 and 45 days of treatment for the high and low concentrations, respectively. While significant decrease in body weight gain after 60 days of treatment with low concentration $(75 \mathrm{ppm})$ and after 60 , 75 and 90 days of treatment by 150 ppm were induced. The liver, kidney, spleen, lung, heart and brain weights of rabbits were not affected after 90 day of treatment with different concentrations of profenofos. Varies degrees of harmful changes in the histological structure of liver were observed according to the concentration of the used profenofos.

Such harmful changes of the examined organs are in accordance with the biochemical and physiological results obtained and each confirms the other.

\section{REFERENCES}

Ahmed, M.M., L. Sahar, F. Nasir and R. Minhas, 2000. Pesticide induced changes in secretaryactivity of the thyroid gland in rats. Pakistan. J. Zoo, 32(4): 333-336.

Canadian Pest Management Regulatory Agency. Health Canada. Florasulam EF1343 Suspension concentrate Herbicide. September 21, 2001.Cited in http://www.hc-sc.gc.ca/pmra-arla/english/pdf/reg/reg 2001-12-e.

Cannon, S.B. and R.D. Kimbrough, 1979. Short-term chlordecone toxicity in rats including effect on reproduction, pathological organ changes and their reversibility. Toxicol. Appl. Pharmacol., 47:469-476.

El-Said, M.M., 1997. Eco-toxicological behavior of some pesticide with special references to haemogram and calcium metabolism in laboratory animals. Ph.D. Thesis, inst. of environment .Studies and research. Ain Shams Univ.

Fujitani, T., Y. Tada, A. Fujii, M. Kimura and A. M. Yoneyam, 2000. Sub-chronic toxicity of chlorophorm (CIPC) in ICR mice. Food. Chem. Toxicol., 38(7): 617625.

Gupta, R.C., 1994. Carbofuran toxicity. Journal of toxicology and Environmental Health, 43 (4):383.

Harris, H.E., 1898. Cited by Carleton, M.A.; Drury, R.A.B.; Wallington, E.A. and Cameron, H. , 1967. $4^{\text {th }}$ Ed. Oxford univ. Press, New York Toronto.

Hayes, A.W., 1994. Principles and methods of toxicology. $3^{\text {th }}$ Ed. PP. 649-672.

Ibrahiem S.M.S and M. Kobeasy, 2005. Physiological responses in blood, liver, kidney and thyroid functions due to drinking water polluted by profenofos in rabbit. Under publication.

Kaneko, J.J., J.W. Harvey and M. L. Bruss, 1997. Clinical Biochemistry of domestic Animal. $5^{\text {th }}$ Ed., Academic Press. Inc., Harcourt Brace-Javanovich Publishers. San Diego, New York,

Kims Berkeley, Boston, London, Sydney, Tokyo, S.G. Toronto.Kim, Y.J. Suirh, Y. Sohn, J.K. Yoo, J. W. Lee, A . Liem and J.A. Miller, 1998. Inhibition of vinyl carbomate- induced hepatotoxicity, mutagenicity and tumorrgenicity by isoprophl -2- (1,3dithietane -2- ylidene) -2- [N - (4-methylthiazol-2-yl) carbomoyl] acetate (Y H 439). Carcinogenesis, 19 (4): 687-690. 
Mohamed O.S., K.E. Ahmed, S.E. Adam and O.F. Idris, 1995. Toxicity of cotoran (fuometuron) in Desert sheep ;.Vet Hum Toxicol 37(3):214-

Shaker, N., G.A. Hassan, F.D. El-Nouty, Z. Abo-El-Ezz and G.A. Abd-Allah, 1988. In vivo hronic effect of dimethoat and deltamethrin on rabbits. J. Environ. Sci. Health, B23 (4): 387-399.

Siroki, O., U. Undeger, L. Institoris, M. Nehez, N. Basaran, L. Nagymajtenyi and J. Desi, 2001. A study on geno and immuno-toxicological effects of sub-acute propoxur and pirimicarb exposure in rats. Ecotoxicol. Environ. Saf., 50(1): 76-81.

Snedecor, G.W. and G.W. Cochran.,1980. Statistical method. $6^{\text {th }}$ Ed. The Iowa state university.Press Ames, USA.

Undeger, U., L. Institoris, O. Siroki, M. Nehez and J. Desi, 2000. Simultaneous geno and immunotxicological investigations for earlly detection of organophosphate toxicity in rats. Ecotox. Environ. Saf., 45(1): 43-48. 


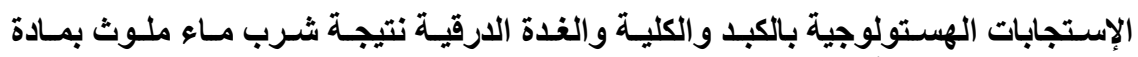
البروفينوفوس فى الأرانب الأبون

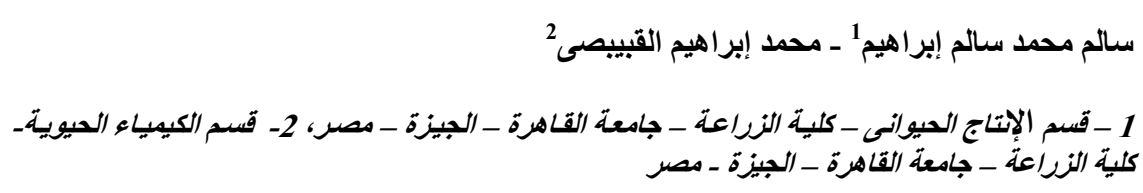

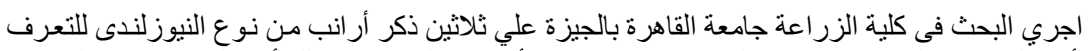

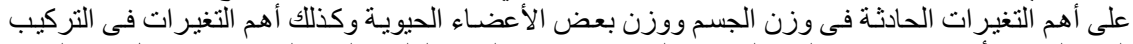

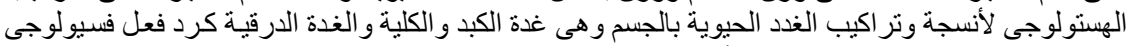

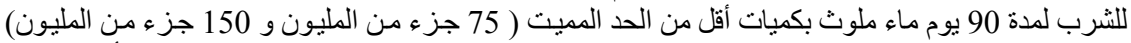

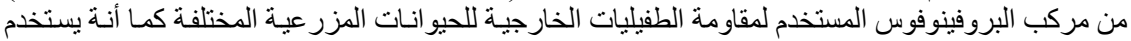

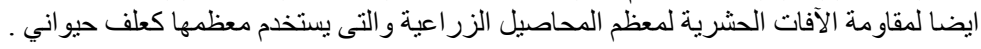

اولا/ التغيرات الحادثة فى وزن الجسم والأعضاء الحيوية:

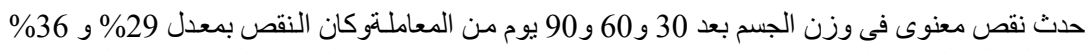

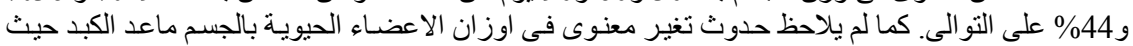

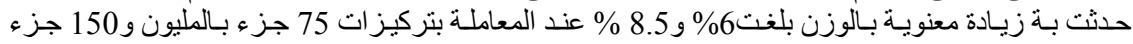

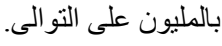

ثانيا / التغيرات الهستولوجية بالكبد التي تستخدم كلديل علي حدوث التغيرات في وظائف الكبد ويمكن

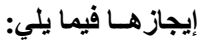

حدوث احتقان في الوريد الرئيسي وكثرة الخلايـا المناعية التي تحبط بالخلايـا الميتـة كرد فعل طبيعي

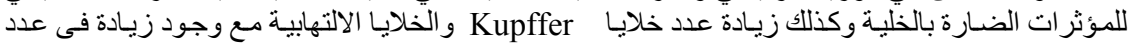
الخلايا الطلائية (Hyperplasia) بالقناة الصفر اوية كمؤشر لإمكان حدوث سرطان علي الددى الطويل.

ثالثا / التغيرات الهستولوجية بالكلية التي تستخدم كدليل علي حدوث التغيرات في وظائف الكلى ويمكن

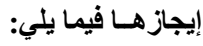

حدوث احتقان دموي ونزيف في كل من القثره( (Cortex) و النخاع( Medulla) وحدوث إرتثاحات

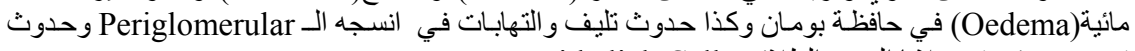

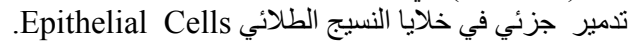


رابعـا / التغيـرات الهــتولوجية بالغدة الدرقيـة كليليل علي حدوث التغيرات في وظـائف الارقيـة ويمكن

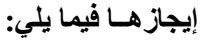

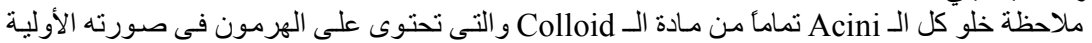

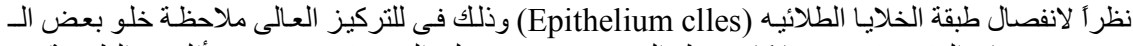

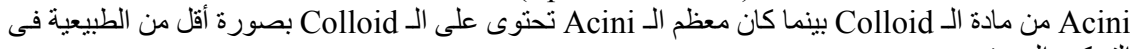

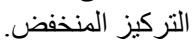

